poder. Assim, propomo-nos a escutar a enunciação das trabalhadoras domésticas sindicalizadas como uma enunciação subalterna.

Concluímos que o ativismo político das trabalhadoras domésticas produz um saber que articula classe, raça e gênero, que nos permite problematizar a narrativa hegemônica da nação, desestabilizando os seus significados culturais hegemônicos, estruturados pelo mito da democracia racial e do "bom senhor" ou "boa senhora".

Palavras-chave: trabalhadora doméstica, sindicato, raça, gênero, classe, teorias da descolonização, saberes subalternos.

\title{
O que o Congresso Nacional brasileiro pensa sobre a criminalidade
}

\author{
Laura Frade Rodrigues
}

Curso: Doutorado em Sociologia

Data da defesa: 30 de março de 2007

Orientador: Prof. Dr. Pedro Demo

\section{Resumo}

Representações do Legislativo Federal brasileiro sobre a criminalidade. $\mathrm{O}$ objetivo do trabalho foi explicitar o que o Congresso Nacional pensa a respeito do tema. O período sob análise foi a Qüinquagésima Segunda Legislatura (2003/2007) que, ao longo da história do Parlamento brasileiro registrou o 
maior número de indícios de ilegalidades cometidas pelos próprios parlamentares. Trabalhamos com a hipótese de que o Congresso Nacional, elaborador da lei, não tem consciência do conjunto de imagens envolvidas na discussão da matéria e que elas intervêm em sua função como estruturador do interdito, da margem, expressa sob a forma de norma legal.

A pesquisa teve início com o mapeamento das proposições apresentadas ao longo do período, quantificando-as por tipo de proposição e iniciativa por Partido Político e por Estado. Na seqüência, foi aplicado às lideranças partidárias, parlamentares formadores de opinião, consultores do Legislativo e assessores da área pública e privada, que intervêm na matéria, questionário destinado a identificar as representações sociais vigentes sobre: natureza humana; contato com a realidade criminal brasileira; definição da criminalidade; suas causas; papel da Lei, do Legislativo, do parlamentar e do indivíduo em relação ao tema e dificuldades para o debate da criminalidade no Congresso.

A hipótese de desconhecimento dos elaboradores legais sobre representações sociais influentes no trato do tema se confirmou. Foi possível concluir que durante a Qüinquagésima Segunda legislatura aqueles que se envolveram no debate a respeito do crime e da criminalidade foram em sua maioria homens, de alta instrução, formadores de opinião, na faixa da meia-idade, que conhecem pessoalmente a realidade do crime no Brasil, e que têm uma imagem bastante negativa do transgressor, com quem não se identificam. Há prevalência da corrente que considera ser sociológica a origem do crime, mas ainda existem aqueles que defendem a origem genética, bem como se registra um crescimento da participação das representações religiosas sobre a matéria.

Essas imagens tendem a ser perpetuadas pela ausência de abertura a novas formas de pensar a questão. A mídia é a principal fonte de informação sobre o assunto. A literatura especializada, 
segundo os elaboradores legais, demanda um tempo de que não dispõem. O Congresso agiu de forma casuística. Faltou vontade política e não recursos. Constituiu-se um sentimento de impotência e registros de insatisfação diante da postura do Executivo. Mostrou seguir a tendência vigente em outros Parlamentos do mundo para o endurecimento no trato com o criminoso, praticamente nenhuma preocupação com sua recuperação e um trabalho focado quase que exclusivamente no crime "do pobre," sinalizando que a elite não é vista como autora na criminalidade.

Palavras-chave: criminalidade, representações sociais, Congresso Nacional, Brasil.

\section{Somos todos brasileiros? Estudo sociológico sobre a moderna divisão do trabalho social brasileira (trajetórias ocupacionais de trabalhadores brasilienses da construção civil - 1992/2003)}

Marcelo Alvares de Sousa

Curso: Doutorado em Sociologia

Data da defesa: 26 de abril de 2006

Orientadora: Prof $^{\mathrm{a}}$ Dr $^{\mathrm{a}}$ Christiane Girard Ferreira Nunes

\section{Resumo}

O tema da pesquisa é o moderno vínculo social brasileiro e suas tendências contemporâneas de evolução, do ponto de vista da divisão do trabalho social. O estudo da integração social e sistêmica 